\title{
Stained Appearance
}

National Cancer Institute

\section{Source}

National Cancer Institute. Stained Appearance. NCI Thesaurus. Code C94578.

Marked or discolored by foreign material. 